\title{
Application of Syariah Education Systems in Accounting Student in Kupang State Polytechnic
}

\author{
Rosmiati, Putri Ayu Pratiwi, Syahrul Bahari \\ \{sabenagroup@gmail.com, puteriayu.pratiwi@gmail.com, syahrulb99@gmail.com\} \\ Politeknik Negeri Kupang
}

\begin{abstract}
Research shows that instruments can be used in this study based on the population in Kupang State Polytechnic in Accounting major, witch aim other purposes to promote a picture of students accounting for understanding of Islamic Pawnshops. With various problems, among others, Islamic pawnshops are not widely known to the public. The method of this research is Simple Random Sampling (random), survey with the approach of qualitative and qualitative analysis totalling 30 people collecting data using a questionnaire. The research used in this study is applied research. Furthermore, the implementation in the determination of the tariffs for siran services is usually called ijarah rates in accordance with the number of loans given. From the results of these studies indicate that students can understand the difference between conventional pawnshops and Islamic Pawnshops. Financial institutions function to provide credit to the community on the basis of pawn laws.
\end{abstract}

Keywords: Application of Syariah Education Systems in Accounting Student in Kupang State Polytechnic

\section{Introduction}

Research data collection on the understanding of accounting students taken from students who have gotten a topic in Syariah economics can be done using test instruments. The form of the test used to collect data in this study is scoring system by using a questionnaire of the old category of instruments that is strongly agree, agree, less agree, disagree and strongly disagree by using the Likert scale choice of answer scoring by response choices indicating the level.

This research method is Simple Random Sampling (random), survey with quantitative analysis approach to collect data using questionnaires. Data is proceed using SPSS assistance. The Analysis Tool used in this study is multiple linear regressions.

Research conducted by Roikhan (2017) concluded that first, Syariah pawnshop had the highest efficiency level of $100 \%$ for a period of 7 years from 2008 to 2014 . Whereas the competitors only had an average efficiency level of $97.42 \%$ for 7 years in the same time span. Secondly, efficiency indicators consisting of inputs and outputs such as operating expenses consisting of wadiah entrusted bonus expenses, administrative and general expenses, salary and benefits 
expenses, and other expenses as well as murabahah margin income, service income, and influential qardh loans significant to the growth of Pawnshops Syariah assets. Third, the prospect of Pawnshops Syariah assets with inorganic actions will be able to provide a value of Rp 116 trillion in 2025.

These two principles also distinguish between Conventional Pawnshops and Syariah Pawnshops; Applying the Pawnshops system in accordance with the principles and rules of syariah for Muslim communities can help them obtain loans to meet their needs, without burdening the heavy burden of repaying loans added to interest. Unlike conventional financial institutions that rely on the interest system, Islamic financial institutions prioritize profit sharing systems, rental systems, and trading systems that do not use the usury system at all. Based on the description above, researchers conducted research on understanding of Islamic financial institutions.

\section{Method}

This research was conducted at Accounting Department of Kupang State Polytechnic based on the reason that the plotting location was due to the absence of a local content curriculum in Islamic economics courses. The objectives of this research include obtaining a description of students' understanding of syariah pawnshop understanding, by looking at several financial institution variables with visits to conventional pawnshop and syariah pawnshop that foster an understanding of syariah pawnshop for accounting students. The sample in this study were individuals from students or groups of students in the fourth semester as many as 30 people from the freshman population which randomly taken.

\subsection{Research population}

Number of students in the first semester or fourth semester majoring in accounting at the Kupang State Polytechnic totaled 334 people, grouped into 8 classes and. The population referred to in this study is the first semester students taken 30 people. This research method is survey research which used quantitative analysis approach, in order to test these factors that influence the attitudes, motivations and interests of student entrepreneurs. As the method of data collection, the researcher used questionnaire as the instrument with 30 respondents.

\subsection{Data collection procedure}

The way how to collect data in a study can be done by two types of data resources, namely primary data (respondents) and secondary data (supporting). Both of these data are very 
important or necessary for the accuracy of the amount of information relevant to data about research variables and to simplify the data to be collected, so the conclusion could be made from data which has been collected.

\section{Research result}

The Accounting Department is one of the five majors in Kupang State Polytechnic (PNK) namely; accounting, business, civil engineering, electrical engineering and mechanical engineering.

A breakthrough could be made through this research in order to be developed on the topic of Islamic economics as one of the subjects discussing Islamic economics and Islamic pawnshop. The sample in this research was taken from first semester students who had just gotten a course in financial institutions. The identity of respondents in this study include, first semester students, respondents were randomly drawn as many as 30 people from the first semester population of accounting students.

\subsection{Instrument test results}

The results of the study are strongly determined by the instrument or measuring tools that used, if the instrument used was not or less valid, then the results of the instrument's external validity were tested by comparing it to look for similarities between the existing criteria on the instrument with empirical facts that occur. Therefore, the research instrument used must be tested whether it is valid and reliable. In order to test the instruments, this study used a validity test tool.

Data collection in this research about student understanding after getting the topic of Islamic economics can be done using test instruments. The form of the test used to collect the data in this study used scoring system through a questionnaire of the old category of instruments that is strongly agree, agree, less agree, disagree and strongly disagree by using the Likert scale choice of answer scoring by response choices indicating the level.

\section{Analysis}

The analysis conducted through multiple regression analysis using SPSS 23.0 as many as two variables that aim to determine whether or not the influence of variables (X1) and (X2) against $(\mathrm{Y})$, then $\mathrm{t}$ test performed to determine whether or not there is a partial effect (alone) that treated each given a free variable $(\mathrm{X})$ with respect to $(\mathrm{Y})$. The $\mathrm{F}$ test aimed to find out whether 
or not there is a simultaneous (joint) influence given by the independent variable $(\mathrm{X})$ to the dependent variable $(\mathrm{Y})$, then the coefficient test is terminated, functioned to find out what percentage of influence the variable (X) has simultaneously on (Y). This analysis tests the following hypothesis:

$\mathrm{H} 1=$ there is an influence of conventional pawnshop (X1) on the understanding of syariah pawnshop $(\mathrm{Y}) . \mathrm{H} 2$ = there is an influence of syariah pawnshop (X2) on understanding syariah pawnshop (Y). H3 = there is an influence (X1) and (X2) simultaneously on (Y). The confidence level is $95 \%, \alpha=0.05$.

The foundation for make decision was the $t$ test and $F$ test, namely the $t$ test includes: a). If the sig value $<0.05$ or $t$ calculation $>t$ table then there is influence of the variable $(\mathrm{X})$ on the variable $(\mathrm{Y})$. $\mathrm{b}$ ). if the sig value $>0.05$ or $\mathrm{t}$ calculation $<\mathrm{t}$ table then there is no effect $(\mathrm{X})$ on (Y). look for $\mathrm{t}$ table $=\mathrm{t}(\alpha / 2 ; \mathrm{n}-\mathrm{k}-1$ or see table $\mathrm{t}$ distribution of values. Then the $\mathrm{F}$ test is tested with a). If the sig value is 50.05 , or $\mathrm{F}$ Calculation $>\mathrm{F}$ table then there is a variable $(\mathrm{X})$ effect simultaneously on (Y). b). If the value of sig $>0.05$ or $F$ calculation $<F$ table then there is no effect of variable $(\mathrm{X})$ simultaneously variable $(\mathrm{Y})$ or see table $\mathrm{F} 0.05$ distribution.

\section{$5 \quad$ Hypothesis testing}

In order to be able to predict how the effects itself, we must find the regression equation first, from the three instruments developed to capture data about these effects. Testing the H1 and $\mathrm{H} 2$ hypotheses with the $\mathrm{t}$ test

\subsection{The influence of first Hypothesis (H1)}

In table 1 sig value for $(\mathrm{X} 1)$ to $(\mathrm{Y})$ were about $0,000<0,05$ and $\mathrm{t}$ hitung 3,966 $>\mathrm{t}$ tabel 2,052 (30 sample). Thus, it can be conclude that $\mathrm{H} 1$ is accepted, there is an influence of (X1) to (Y).

\subsection{Influence of the second hypothesis (H2)}

In table 1 , sig value for $(\mathrm{X} 2)$ to $(\mathrm{Y})$ about $0,700 \mathrm{sig}>0,05$ and $\mathrm{t}$ calculate $0,389<\mathrm{t}$ table 2,052 (30 sample). Thus, it can be concluded that $\mathrm{H} 2$ is rejected; there is no influence from (X2) to (Y).

\subsection{Influence of the third hypothesis (H3)}


The third hypothesis (H3) used anova, anova stands for Analysis of variance. It is a statistical test procedure similar to $t$ test. The results of the multiple linear analysis tests ( $F$ test). $F$ test, if the value of $\mathrm{sig}<0.05$, or $\mathrm{F}$ calculation $>\mathrm{F}$ table then there is a variable $(\mathrm{X})$ effect simultaneously on (Y). Value of $0,000<0,05, \mathrm{~F} \mathrm{15,393}>$ F 3,32. Then, there is the effect of variable (X) simultaneously on (Y).

\section{Coefficient of determination}

The coefficient of determination ( $\mathrm{R}$ square or $\mathrm{R}$ squared) or caused by $\mathrm{R} 2$ which is meaningful as a contribution of influence given independent variables or independent variables $(\mathrm{X})$ to the dependent variable or dependent variable (Y), or in other words the coefficient of determination was useful to predict and see how much the contribution of influence that is given variable (X) simultaneously to variable (Y). R2. Based on the sum output above, it can be said that $\mathrm{R}$ square value of 0.533 , implied the influence of variables (X1) and (X2) simultaneously on the variable (Y) of $53.3 \%$.

\section{Discussion}

This research was conducted to determine the topic of syariah pawnshop does not or significantly influence to the understanding of syariah pawnshop of the students. Based on 30 respondents that used as source of research data, instrument testing showed that the instrument can be used in this study based on the validity test and the reliability test of all question items is valid because each item corrected Item-Total Correlation has greater value than the minimum standard (0.3), Cronbach's Alpha value $(0.810)>0.374$. It means that all the questionnaires in this study are reliable.

The value of the multiple correlation coefficient indicates the number $\mathrm{R} 0.533$ stated that the value range of $\mathrm{R}$ values is 0 to 1 including the medium category, it can be caused by the intended sample still requires guidance on understanding syariah pawnshop. While the small Adjusted R Square value is still in the standard range, but its accuracy is poor in the range of Adjusted R Square value is 0 to 1 is still below the number $<0,533$

From the results of the regression analysis output can be seen that the F value about 15.393, the significance level using a $=5 \%$ (significance of $5 \%$ or 0.05 ), the results of the hypothesis test produce that the value of $\mathrm{sig}<0.05$, or $\mathrm{F}$ calculate $>\mathrm{F}$ table then there is an influence variable (X) simultaneously with (Y). Value of $0,000<0,05, \mathrm{~F} \mathrm{15,393}>\mathrm{F} \mathrm{3,32}$. then there is the simultaneous influence of variable $(\mathrm{X})$ on $(\mathrm{Y})$. 


\section{References}

1. Ascarya Diana Yumanita (2005).Bank Syariah: Gambaran Umum. pusat pendidikan dan studi kebanksentralan (ppsk). Bank Indonesia

2. Anas Sudijono (1996), Pengantar Evaluasi Pendidikan, Raja Grafindo Persada. Jakarta.

3. Al-Hafizh,M(2013),Pengertian Pemahaman Dalam Pembelajaran. http://www.referensimakalah.com. Diakses 12/5/2018

4. Aghna. (2014). Motif Uang. https://www.academia.edu diakses 13/5/2018

5. Raikhan (2017). Efisiensi Pawnshops Syariah dan Prospek Pertumbuhan Aset di Indonesia. al-Uqud: Journal of Islamic Economics Volume 1 Nomor 1, Januari 2017 EISSN 2548-3544, P-ISSN 2549-0850 Halaman 59-82.

6. Nasution, R.S (2016). Sistem Operasional Pawnshops Syariah Berdasarkan Surah AlBaqarah 283 pada PT. Pawnshops (Persero) Cabang Syariah Gunung Sari Balikpapan. Al-Tijary. Jurnal Ekonomi dan Bisnis Islam 2016, Vol. 1, No. 2, Hal. 93-119. 